Sign Systems Studies 29.2, 2001

\title{
On signs, memes and MEMS: Toward evolutionary ecosemiotics
}

\author{
Paul Bouissac \\ University of Toronto \\ 253 College Street, P.O. Box 429, Toronto, M5T 1R5, Canada \\ e-mail: bouissa@attglobal.net
}

\begin{abstract}
The first issue raised by this paper is whether semiotics can bring any added value to ecology. A brief examination of the epistemological status of semiotics in its current forms suggests that semiotics' phenomenological macroconcepts (which are inherited from various theological and philosophical traditions) are incommensurate with the complexity of the sciences comprising ecology and are too reductive to usefully map the microprocesses through which organisms evolve and interact. However, there are at least two grounds on which interfacing semiotics with ecology may prove to be scientifically productive: (a) the very looseness of semiotic discourse can be an important catalyser for multidisciplinary interactions, an important condition for the emergence of truly holistic ecology; (b) the present semiotic conceptual apparatus is not carved in stone. All its notions, frames of reference and types of reasoning can evolve in contact with the problems encountered in evolutionary ecological research. Semiotics, as an open-ended epistemological project, remains a proactive intellectual resource. The second issue raised by this paper is precisely to call attention to the opportunity provided by recent developments for rethinking and furthering semiotic inquiry. An attempt is made to show that counterintuitive theories such as memetics and new frontiers in technology such as nanotechnology, could help recast ecosemiotics along more intellectually exciting lines of inquiry than the mere rewriting of ecological discourse in terms of the traditional semiotic macroconcepts. It goes without saying that memetics and nanotechnology are not presented here as definitive solutions but simply as indicative of possible directions toward a comprehensive evolutionary ecosemiotics that would radically transform the basis of the 20th century semiotic discourse and its ideological agenda.
\end{abstract}




\title{
1. Is ecosemiotics a paper discipline?
}

\author{
[...] ecological relations are based on \\ meaning; they are semiotic. \\ Ecosystems, no less than cultures, are \\ contingent upon communication.
}

Alf Hornborg (1996: 53)

The introduction of semiotic models and terminology into the discourse of various disciplines has given rise to compound names on the model x-semiotics such as zoosemiotics (Sebeok 1970), neurosemiotics (Ivanov 1979), and socio-semiotics (McKellar 1987), to mention only a few. Far from referring to corresponding disciplinary institutions, such labels indicate on the part of their proponents a sensibility to the communication dimension of the domains investigated respectively by zoology, neurology and sociology rather than an epistemological reliance on a specified methodology aimed at new scientific discoveries. It mostly consists of interpreting or reinterpreting acquired knowledge through rephrasing propositions in terms of signs, sign categories and other notions used by some semiotic schools. Typically, these hybrid lexicons indicate the interests of some individual semioticians in a variety of scientific discourses in which they perceive some potentially sign-relevant information which they work into their own philosophical arguments (e.g., Koch 1986). More rarely, some individual scientists attempt to integrate their compartmentalized research within the more comprehensive perspective that various brands of semiotics seem to afford (e.g., Deacon 1997, Hoffmeyer 1996). Both sides usually lack a sense of the historical complexity of the "other culture" and interface with a limited subset of information resources. However, these partial and biased recontextualisations appear to play a significant part in constructing overlapping domains which may prove mutually beneficial through a process of "cross-fertilization", although it is sometimes difficult to pinpoint actual results either in the way of changes brought about in the semiotic conceptual apparatus or in the form of experimental strategies that would be inspired by some semiotic notions or models. By and large, semioticians delve in speculative discourse rife with thought experiments and anecdotal examples and only occasionally engage in serious meta-analyses of some sectors of scientific literature in order to garner critical evidence in support of their arguments (e.g., Sebeok 1968). Conversely, some scientists who aspire to break free 
from the intellectual constraints of their methods find in semiotics a basis, or an alibi, for their philosophical or religious speculations (e.g., Hoffmeyer 1996). These general strategies provide, nevertheless, opportunities for interactions. But the dialogues that are thus prompted most often remain on the level of inconsequential mutual interpretations and, in some cases, are simply used as mutual status reinforcement strategies. If these characterisations accurately reflect the nature of these disciplinary interfacings, they lead one to wonder whether the many "hyphenated disciplines" are mere sociological or epistemological chimera that exist only on paper, or whether they actually designate agenda that offer promising avenues of inquiry based on new premisses.

However, so much is still to be known that intellectual skepticism and epistemological despondency in this regard should not be in order. The potential for cross-fertilisation should not be discouraged but cannot be taken for granted either. It seems that chances of progress can be assessed on several grounds.

First, the forces of inertia of disciplinary cultures must be taken into account. These forces of resistance have no relevance to the epistemological value of the merging of disciplines. They apply equally within the sciences and within the humanities. For example, the obstacles encountered in the 1990s by attempts to fuse evolutionary biology and developmental biology, a movement known as "evodevo" (Pennisi, Roush 1997), bear witness to the sociological strength of disciplinary incommensurability and resilience, often masking deeper ideological rifts (Kull 2000). It seems at times that institutionalisation of cross-disciplinary domains requires no less than a scientific revolution and the creation of a new scientific paradigm following the pattern elucidated by Thomas Kuhn and aptly summarized in the obituary written by David Hull (1996).

Secondly, the disciplines brought together must meet compatible standards in terms of methodology and level of resolution. For instance, while "neurosemiotics" may sound like a good idea, there is no compatibility between the macrolevel of current semiotic categorisations which are based on phenomenological intuitions and logical reasoning, and the microlevel of description and analysis found in the contemporary brain sciences, even in the branches devoted to the neurological understanding of well-defined cognitive processes (e.g., Calder et al. 2001). Bridged disciplines must have an equivalent capacity for producing counter-intuitive knowledge rather than commonsensical and redundant propositions (Kestenbaum 1998). 
Thirdly, there must be a gnoseological or pragmatic urgency that requires epistemological integration and methodological harmonisation between disciplines that initially emerged as separate social entities. When it becomes obvious that some major problems confronting human societies, locally or globally, cannot be solved with the resources of a single discipline, a powerful pressure develops to create at least partial integration of research in the form of a task force for short-term solutions and long-term research and development programs for strategic responses. Among the most obvious cases of this process are the functional, albeit partial, merging of sociology and medicine, history and climatology, and neurology and linguistics. The recent apparition of the word "ecosemiotics" raises the issue of whether it is a symptom of such an urgency or merely an opportunistic phantasy. Is ecosemiotics a paper discipline or does it have epistemological teeth? Does rewriting ecological interactions as communication make a difference or is it a futile stylistic exercise?

\section{Philosophy, science or politics?}

It is by languaging that the act of knowing [...] brings forth a world.

H. R. Maturana, F. J. Varela (1987: 234)

The emergence of ecology as a domain of specialised research concerned with the understanding of interactions both among organisms and between organisms and their environments was in part a response to the inability of individual disciplines to come to grips with the complexity of problems generated by industrialisation. The unsustainable exploitation of "nature" which had been perceived at first as an unlimited source of riches, drove home the idea that animal, vegetal and mineral resources formed delicately balanced webs of interrelated food chains. These resources were perceived, on the one hand, as controlling each other in a way that prevented extreme variations in the absence of major cataclysms and, on the other hand, as having a conservative impact on the climate, the chemistry of soil, water and atmosphere, and the reproductive rate of species that were deemed relevant to human interests. Monitoring and controlling these resources required the synergy of a vast array of experts from biologists and ethologists to chemists and physicists. For instance, the Depart- 
ments of Ecology and Evolution at the University of Chicago has a faculty comprising specialists in molecular evolution, population genetics, quantitative genetics, animal behavior, plant and animal ecology, evolutionary theory, systematics, paleontology, and relies also for its curriculum on courses offered in the departments of Organismal and Cell Biology, Biochemistry and Molecular Biology, Molecular Genetics and Cell Biology, Statistics, Geophysical Sciences, Anthropology and Chemistry.

The daunting program of a holistic ecological science - which is still in progress - encountered the resistance of economic and political agencies whose immediate interests are not compatible with the policies inspired by ecological knowledge, which they occasionally label as "bad science". As a result, ecological awareness has taken the form of militancy and has generated a critical discourse and a political agenda aimed at advancing the cause of the preservation of the planet's environment and its biodiversity while often advocating at the same time various forms of social and cultural conservatism. It is therefore important to distinguish scientific ecology as a curriculum and a multidisciplinary research program from political ecology as a set of ideologies and activist movements. It has been shown that both the scientific endeavor and the political agenda have deep roots in 19th century intellectual and political history, reaching into the sources of Romanticism for the latter and holistic approaches to knowledge construction for the former (Nöth 1998).

In this complex and somewhat confusing context, the recent apparition of the notion of "ecosemiotics" (with or without hyphenation) raises the issue of whether semiotics can indeed be justifiably added to the specialties of an ecological curriculum or whether semioticians should look towards the ecological sciences as a source of relevant data, models and methods in order to update their worldview and renew their philosophical arguments. It is the contention of this paper that the second option is a prerequisite for the first one, simply because there is too much discrepancy between semiotics as it stands now and the scientific disciplines upon which current ecological research relies for its advancement. At most, semiotics can provide a flexible epistemological framework for integrating various streams of specialised knowledge as long as its concepts reach an optimal level of resolution and do not remain at the macroperceptual level that characterizes its phenomenology. The first task of semioticians would then be to apprise themselves of today's rather than yesterday's ecological and related knowledge, and see whether they can go beyond the 
simplistic reduction of all processes to communication arcs or triadic relations so as to realize that what they call signs and semiosis is the problem rather than the solution.

\title{
3. Is semiotics an archaic mode of thought, a mythical discourse or a metalanguage?
}

\author{
How far will semiology go? It is difficult \\ to predict.
}

Ferdinand de Saussure (1989: 154)

The main notional currency of semiotic discourse has remained basically unchanged since Augustin of Hippo (Deely 1998). There has been reshuffling and reconfiguring within this basic frame. Debates and controversies have spawned new words. Fringe terminologies have been added, notably from information technologies, but they have often been redefined to suit the earlier conceptual apparatus of the philosophy or "doctrine" of signs. While the generalisation of a basic terminology can be a factor of progress in as much as it contributes, like metaphors do, to the heuristic generalisation of models across various domains of experience, it also carries the risk of "freezing" their perception and interpretation at a particular degree of conceptual resolution. It is symptomatic that by and large the mainstream semiotic discourse has remained, on the one hand, rather impenetrable to evolutionary theory, viz. its fascination for Jakob von Uexküll and his anti-Darwinian stance as Konrad Lorenz (1981) pointed out and, on the other hand, fairly indifferent to the advances of the neurosciences, viz. its continuing obsession with Sigmund Freud and his Gallic epigones in spite of compelling criticisms (Clare 1985). Moreover, semiotics has maintained a level of phenomenological reasoning defined at its lower end by 17 th century microscope technology. This is probably why the nascent ecosemiotic discourse is evoking renewed visions of the "great chain of beings", sometimes reworked into the rhetoric of Gaian "greenspeak" (Harré et al. 1999) rather than articulating a stimulating theoretical and empirical agenda that would command the attention of researchers across disciplinary borders. With its implicit representations of biology, psychology, physics and so on, mostly in folk- or popularised versions, semiotics forms an academic sub-culture which generally finds it difficult to 
interface with other disciplines which consider that basic semiotic terminology and conceptual apparatus lack consistent, operational definitions. Its discourse appears to describe a communication utopia which has little appeal to those minds used to wrestling with complex problems in their daily research practice and the "small change" truths they treasure.

The central notions of "sign" and "communication", for instance, are notions "by default", so to speak, in as much as "something" had to be hypothesized in order to account for phenomena that appeared to be intransitive such as causation at a distance, otherwise unexplainable events, or seemingly disproportionate relations between inputs and outputs. These sorts of virtual objects, the sign or the communication act, were conceptually elaborated in a phenomenological world strictly constrained by the power of resolution of human vision that has been finetuned by evolutionary forces. Hominids have evolved as diurnal organisms who heavily depend on close- and medium-range vision for their survival and reproduction. But eventhough the natural human visual apparatus is obviously adaptive, it is so with respect to a limited set of environmental and social conditions, as are the other perceptual hominid adaptations that define the human "umwelt". Ecological sciences are based on controlled representations that so vastly expand the limits of this "umwelt" and increase so much the level of resolution of its phenomenology that it seems legitimate to wonder whether the present conceptual apparatus of semiotics, including its pivotal notions, can preserve the relative relevance it might indeed have had until the recent past for mapping a meaningful integrative perspective onto the information that is now available. Even in its most restricted definitions, the notion of "sign" is a macro-concept that indiscriminately covers a large number of heterogeneous local processes which now are not only becoming visible and describable but can also be simulated through nanotechnologies below the threshold of natural human perception. Can the virtual universe that has been blindly constructed over the past centuries by the discourse of semiotics be anything more than a sort of epistemological mythology? Or do the general questions this semiotic discourse has raised still constitute a credible ground for further elaborations in view of the expanded knowledge brought forth by extreme technologies and counter-intuitive theories? The argument of this paper is that the latter is probable as long as semiotics discards its obsolete models and transforms itself into an evolutionary ecosemiotics in the most radical sense of these terms. 
All organisms develop and reproduce within a set of environmental constraints of which other organisms, including conspecifics, form an essential component. The prerequisite for the maintenance of life is the constant processing of information that is relevant to the particular conditions which have shaped specific biological profiles. This shaping through adaptation by natural selection never ceases as the environment, both organic and inorganic, is in constant flow and is prone to irregular catastrophic changes. Evolution is a wasteful process. In some species, for instance Felis leo, only approximately $2 \%$ of the cubs reach reproductive age. Drought and floods, predators, parasites, infanticides, epizooties, disruptions of the social group, accidents and the like take their toll. The lucky Serengeti lioness who survives until she comes in estrus is equipped with reliable sensors that allow her to pick up information that matters and to behave efficiently in accordance with the complementary information she garnered from the related group of females within which she has grown up and with which she will later raise her first litter. Whatever the development of this individual may have been, what matters is whether or not she eventually reproduces successfully or contributes to the reproductive success of her siblings. Suppose that, while this lioness is nursing her first litter, a new male happens to displace the resident male and take over the pride. The newcomer will kill the cubs and mate with the lioness who, in such cases, comes quickly in estrus and initiates the courtship ritual. The new litter may have better chance of survival, although it is by no means certain.

The proponents of biosemiotics claim that the whole biological cycle that has been outlined above is a complex semiosic process that takes place both within the organism as it develops and matures, and externally through its interactions with its physical and social environments. They hypothesize that signs necessarily mediate all these processes while they characterize signs in terms of a few abstract relationships. However, the identification of appropriate preys, the coordinated hunting strategies that are characteristic of Felis leo, the monitoring and defense of the pride's territory, the selection of mates, the maintenance of the social bond and the establishment of the ranking order within the group, the collective raising of the young and their assimilating some specific environment-relevant knowledge that has accrued in the group such as the mapping of water holes or the behavior of the local prey, the role of carnivorous predation in the balance and fitness of the herbivorous population and the counterstrategies of the prey species - all these aspects of a successful life 
cycle have been analysed, described and often manipulated in terms of perceptual processes, visuo-motor integrative circuits, hormonal functions and pheromones broadcasting, ritualised interactive behavior, genetic inclusive fitness and so on. One may legitimately wonder what kind of epistemological advantage is yielded through the translating of extremely complex representations of biological microprocesses into a discourse made of approximately a dozen words whose definition is so problematic that semantic debates are still raging among semioticians. Any consistent sub-set of semiotic concepts conceivably may provide an embryonic meta-language, a rare commodity in a context marked by disciplinary gaps which are generally considered a liability for the advancement of knowledge. But this translating does not seem to have any explanatory or heuristic value for biologists, still less so for physicists. It certainly blurs important differences and smooths rough edges. In so doing, it reduces information to a few semantic categories through which a redundant meaning is constructed. It brings a virtual closure to the counterintuitive discourse of scientific knowledge that keeps generating anxiety by upsetting long-held certainties that form the basis of the self. Perhaps the relative success of contemporary semiotics can be accounted for by its capacity to provide a virtual holistic perspective. In certain contexts, fallacies may indeed be temporarily adaptive, perhaps for their own sake. Some, now, would call "memes" such fallacies, a move that has not failed to challenge semioticians.

\section{Theories by default?}

The Idea is an organism, is born, grows and dies like organisms, renews itself ceaselessly. [...] Action is the servant of the Idea.

Jean Piaget (1915: 1)

"Meme", like "sign", is a notion by default. The intriguing constatation that the power of "ideas" or "habits" does not always serve the best biological interest of the organisms who hold them has haunted the human psyche for a long time. Memes and signs are posited because better explanations are lacking. The above quotation, from one of the very first writings by the young Piaget at the beginning of 
World War I, The mission of the Idea, bears witness to the frustration of rational minds confronted to the power of myths and slogans. There has been a consistent discourse of alienation that construed the world of ideas as belonging to another order: divine interventions, spirits' influence, transcendant principles, inspirational or irrational causation, cultural norms, structural laws, emergent and evolving algorithms, and the like. Habits, on the other hand, have been sometimes refered to as forming a "second nature", thus indicating a quasi distinct ontology. From the Vedic texts and Plato, to modern reflections on myths, ritual and language, these seemingly unaccountable forces have been described as agencies that spread among humans and control their behavior. Traditionally explained in terms of supernatural interventions through evil possession or divine inspiration, these phenomena were bound to be recast in the context of evolutionism. Early formulations focused on language whose origin has always puzzled humanity. From Charles Darwin's tentative remarks on the evolutionary characteristics of languages and August Schleicher's explicit attempt to construe languages as evolving and developing organisms, there has been undercurrents among linguists who were not entirely satisfied by strictly functionalist view of language. In this respect, Saussure's notion of "langue" and Chomsky early positing of an "innate grammatical competence" were the result of inferring from linguistic behavior the necessary, but hypothetical condition that must be assumed if this behavior is to be understood. It is in this respect that these notions are "notions by default" since they are proposed because no better explanation can be found rather than because compelling evidence of their presence and action is available. They become objects of belief. The ontological status of both "langue" and "linguistic competence", and their Platonician overtone, have been hotly debated. Saussure himself struggled in notes he never wanted to publish with the contradictions implied in his notion of "langue" in which time was of essence while stability had to be assumed, and Chomsky progressively displaced the ontological locus of "competence" from the Cartesian to the Darwinian paradigm. In recent years, Terrence Deacon attempted a reactualisation of earlier evolutionary theory of language, using, somewhat defensively, the notion of "meme" as parasitic agencies and proposing a counter-intuitive perspective on the relation of language (and other behavioral algorithms) to brain characterized as being co-evolutionary. The "meme" is obviously for Deacon still a notion by default, and he has articulated 
his scepticism through examining the conceptual interface between "memes" and "signs" (Deacon 1999: 1-2).

The meme "meme" has caught the attention of popularisers and there has been a constant stream of books which cash on the "outrageous" claim that humans are infected and manipulated by "invisible parasitic agencies" and that cultures are nothing but the symptoms of such infectious algorithms. In spite of these scientifically unsound speculations, some researchers have endeavored to use this general view as a source of algorithmic and epidemiological models aimed at investigating various aspects of animal and human copying behavior. Such on-going research will provide some grounds for assessing the validity and fertility of the meme hypothesis. If compelling scientific evidence emerged to meet the nagging age-long suspicion that human brains may be "invaded" by "ideas" that determine behavior which may or may not be adaptive from the point of view of human organisms, this new understanding would at the same time transform our views on signs and semiosis. These latter two notions were indeed devised to account by default for at least some of the phenomena the meme notion is meant to explain. Since semiotics is still a speculative and interpretative discipline, let us heuristically consider that memes and signs designate subsets of the populations that comprise the planet earth's ecosystem.

The lion pride which was evoked above does not have to contend only with preys, predators, diseases, droughts and the like. The various symbolic representations of their species and the behaviours they command among human populations have also an impact which can prove as deadly or as beneficial as anything else. In this respect, ideas and their ritualistic consequences, for instance, are agencies which are participants in the ecosystem dynamic of Felis leo as much as Tse tse flies or floods are. The fact that humans carry those ideas does not make any more difference than the fact that some preys may carry parasites which are lethal for the lions feeding on them. Lions, on the other hand, can at times be fatal to the ideas or memes that haunt their niches by destroying their carriers, in particular those who hold the belief that they are immune to feline attacks because of magic or because of utopian worldviews.

Indeed, the memetic hypothesis, which holds that cultures consist of populations of parasitic algorithms able to control their hosts' behavior so as to secure their own replication, does not suggest that memes are immune to the evolutionary constraints which apply to all other organisms and account for their diversity. Actually, as parasites, 
the constraints that limit their survival and replication are compounded by the fact that the survival and reproduction of their hosts are prerequisites for their own success. In addition, following the logic of evolution, memes are bound to compete with each other, as well as, in some circumstances, develop forms of mutualism and symbiosis. It is likely that the consideration of memes as individual entities is a mere theoretical abstraction since there is more biological plausibility that memes always operate in complex micro-ecological combinations that show various degrees of resistance to the evolutionary pressures that come from the changing constraints of their hosts' environment.

Similarly sign processes must be assumed to be limited not only by each other's requirements for transmission capacity, redundancy cost and energy consumption, but also by the absolute thresholds of the organisms' available channels and behavioral resources budget. For instance, the cost of signalling must be carefully monitored from several points of view: energetic expense, time constraints, increased degree of vulnerability coming from the disclosing of the source of the signals and the status of the organism which produces it. Evolution has scooped out, so to speak, by elimination most blurred and ambiguous signalling processes. Early memetic speculations have generated some paranoid images inspired by science fiction rather than rational considerations. This can be expected when a notion emerges by default without any means for representation because of its elusive nature. Human imagination processes the trauma of new information, even if it is purely virtual, through available narratives which are often the only way to formalize a problem in terms of familiar data. Memes, like signs, are theoretical fictions extracted by abductive reasoning from reflective experience. They are Mendelian notions because the macro-level of resolution through which they are conceptualized does not make it possible to assess their genotypic structures visually or by any other measurable means. They are however both intellectually compelling and counterintuitive. The history of human knowledge provides countless examples of processes that were deemed immaterial simply because they were invisible. Memetic speculations should be seen as a step toward defining a new frontier of investigation rather than a theory that is either true or false. If memes are heuristically conceived as parasitic or symbiotic algorithms, they must be represented on the same level of resolution as biological signalling processes because it is at this level that they operate, possibly to exploit at their own advantage complex organisms' evolved adaptive signalling and motivational apparatuses. Then, the risk of being thus exploited 
could be considered as one of the liabilities of these complex signalling systems. However, it is important to keep in mind that, as often occurs in evolution, some exploitations turn out to be adaptive through mutualism and symbiosis. Semioticians have produced detailed categorisations of signs without distinguishing with sufficient clarity those sign processes that are biologically adaptive from those that are culturally adaptive. There has been a tendency to understand the latter as a continuation of the former, as if they were genealogically related along an axis of evolutionary "progress". At the same time, such "progress" has been consistently assessed as a mixed blessing since the destructions (even self-destructions) committed on behalf of cultural imperatives appear to be out of step with any conceivable logic of survival or inclusive fitness. Memetic considerations offer an epochal conceptual opportunity to question these longheld certainties based on the simplistic notions of mimesis and semiosis. But this epistemological agenda will remain a mere virtuality until appropriate technological means and conceptual models enable the observation and representation of these evolutionary and ecological processes at their relevant level of resolution, that is, on the level on which natural selection operates. This is a necessary condition for evolutionary ecosemiotics to come of age.

\section{Memes and MEMS: The new frontier}

This fact-that enormous amounts of
information can be carried in an
exceedingly small space - is, of course,
well known to the biologists, and
resolves the mystery which existed
before we understood all this clearly, of
how it could be that, in the tiniest cell,
all the information for the organization
of a complex creature such as ourselves
can be stored.
Richard Feynman (1999 [1959]:123)

Besides an intriguing paronymy between memes and MEMS - an acronym that stands for Microelectromechanical Systems - no attempt will be made here to relate these two notions with each other in any functional way. Naturally, technological ideas and their appl- 
ications belong to the putative realm of memes and their presence in ecosystems' dynamic is all too obvious through their dramatic impacts, sometimes called the Baldwin effect. What will be simply suggested here is that MEMS first provide a powerful technological metaphor for the appreciation of the scale of resolution on which evolutionary ecosemiotic processes can be observed, represented and simulated, thus opening the way to a scientific revolution. 1965 Nobel prize Richard Feynman outlined in the 1950s a vision that merged the defining tool-making abilities of humans with their newly acquired knowledge of atomic and sub-atomic representations. His landmark lecture of 1959 to the American Physical Society, entitled "There is plenty of room at the bottom", initiated a movement toward extreme technological miniaturisation. While nanotechnological applications have started to revolutionize contemporary industry, medicine and information technologies, their potential for simulating neurological processes on a commensurate scale will undoubtedly open the way to forms of artificial semiotics in which the ecology of these processes will cease to be a purely speculative exercise but will address actual pressing problems the solution of which is bound to shed light on, and profoundly transform, traditional notions of communication and semiosis. All technological innovations have profoundly impacted the human perception, conception and manipulation of the environment and have altered its ecosystems' communication webs. Since Feynman's days, MEMS have come of age. They are mass constructed on micrometers scales. They can sense, control and actuate. They can operate individually or in arrays and generate effects on the macro scale.

All the interactive processes which are phenomenologically described or simply grossly categorized as signs in the semiotic literature are grounded on the perceptual and cognitive apparatus of organisms who have evolved under a great variety of constraints. Some of these constraints have evolved at the same pace, thus creating the conditions for co-evolutionary processes. The factorisation of all these conditions for understanding a single organism at a given time is a daunting task that mostly eludes human cognitive capacities, which have been shaped by the necessity of handling only those factors that were relevant to immediate survival. Beyond a certain level of complexity humans must rely on their ability to simplify phenomenological data and to conceptually manipulate these simplifications so as to extrapolate from limited experience predictive models and pragmatic algorithms. This evolved competence itself is the object of intense 
speculations and no compelling explanatory theory has emerged yet. However, a few assumptions can be reasonably made: the human organism relies mostly on visual information for its physical and social survival; the degree of resolution of its perceptual apparatus constitutes an absolute threshold for the information it can process; awareness (both perceptive and proprioceptive) applies only to a limited subset of this information; tool-making is a determining asset that evolution continues to select, as world wide conflicts between technology and demography tend to show.

All the main concepts of semiotics come from natural philosophy which is dependent on natural perception and awareness. Natural ecology factorises all the "objects" that have a perceptual or proprioceptive definition, that is, they are viewed or imagined as discontinuous representations in space and time, and their transformations usually appear as sudden rather than progressive and continuous because of the way in which adaptive biological clocks determine the phenomenology of time processes. In semiotic discourse, interactions at a distance are causally ascribed to the action of signs emitted from an "object" toward another. These "objects" are foregrounded with respect to a background of gases, waves, radiations, and possibly other forms of matter, that are invisible to the human perceptive apparatus because the latter has evolved within a range of niches in which this background can be treated as a constant, at least during the span of time involved in terrestrial mammalian evolution. In the theorising of organismic interactions, signs and their "parts" and "varieties" have been conceived as a virtual ecology that models and parallels the natural ecology which is accessible to human awareness. Actually, in its popularised forms, semiotics has variously created visions of the world in which natural and artificial "objects" are mixed with natural and artificial "signs" that fill the gaps, so to speak, of human perception. In some extreme cases, these virtual ecologies generate virtual ontologies that extend to the whole universe for the best or the worst of the populations which foster them. Naturally, most of these intellectual appropriations, while being adaptive to a degree at least in the short term, remain virtual and may be totally inconsequential in the sense that such narratives do not generate the conditions for new counterintuitive knowledge since they amount to presupposing that the "problems" are solved. Some brands of contemporary ecosemiotics simply implement such programs with conceptual and terminological adjustments to take into account the parallel discourse of utopian scientific ecology. 
But some of these virtual constructs happen to be consequential on the scale of evolutionary time. The dialectic of modelling and observing coupled with tool-making abilities has lead humans beyond the naturally evolved limits of their visual system. This is a very recent event whose consequences have not yet fully impacted human worldviews and awareness. Humans have evolved as mostly visual organisms, that is, at least some individuals have survived long enough to reproduce and natural selection has streamlined welladapted visual systems which provide sufficient vital information regarding kin recognition, prey identification and predator avoidance. These adaptations apply equally well to the identification of edible vegetables in a forest and to canned vegetables in a grocery store. The same avoidance behaviors apply to a charging elephant and to a speeding car, with appropriate adjustments. But they do not apply to sorting out bacteria and viruses, nor to avoiding bullets. In addition to such limitations, this visual system's complexity and its sensitivity to extreme conditions and to aging is an important source of vulnerability. It is far from optimal and its shortcomings have prompted remedial strategies in the form of optical knowledge and technology. Seeing better, further and beyond the natural threshold of resolution has been a powerful motivation for tool-making organisms who come to understand the liabilities of their natural vision. The microscope opened up a realm of experience on a scale that had not been available to humans during the evolutionary process. Of course, scale is a relative notion. What may be non-perceptible for a visual system is a whole rich and diverse environment for another. The non-visible has been consistently construed as immaterial by human efforts to account for causes that elude observation. It would seem that, fundamentally, a notion by default is one that fills a visual gap. The semiotic discourse speaks of the actions of signs as agents whose ontological status is ambiguous, to say the least. The root metaphors of this discourse are relating to ballistic or to the logistics of traffic regulation and cybernetic communication. In the semiotics of communication, the medium is not a marked dimension of the models. But the medium is considered a "less-interesting" component. In the semiotics of signification, the medium is taken for granted. Signs and systems of signs, said to be made of "relations", circulate in a virtual universe, a sort of semiotic "ether", a signifying utopia. But all the processes described as biological sign processes are physical events necessarily involving energy consumption, occupation of determined space and time, and evolutionary risks in as much as organisms who signal 
spend energy and disclose by the same token their location and current status. Furthermore, signalling apparatuses carry also a cost that has driven them toward extreme miniaturisation. Packing the maximum number of circuits in a minimum of space, preferably well protected without being too cumbersome, is an evolutionary imperative, a natural nanotechnology, that has shaped the semiotic organs and pushed their dimensions below the threshold of human visual and conceptual resolutions. The cost and potential pay-off of extreme signalling has been well theorized in the framework of the "handicap principle" (Zahavi, Zahavi 1997), but it is likely that this theoretical understanding is not limited to the most obvious cases observed in courtship behavior and mate selection.

In view of advances in the visualisation and understanding of neuronal processes, and in the parallel developments of nanotechnology (which, as it was pointed out above ultimately could enable the observation, representation and simulation of the former), it can be anticipated that the macro concepts of semiotic phenomenology will become obsolete and will be replaced by counterintuitive theories with unpredictable consequences. This is where lies, in my opinion, the contemporary excitement caused by the emerging notion of ecosemiotics. Semiotic algorithms are physically embodied or are nothing. As sets of instructions, they are endowed with a form of dynamism which is able to mobilise or exploit the motivational systems of the human brain with whose structures they are commensurate. Thus, they are bound to compete for space and energy, for survival and reproduction. Only within the conceptual framework of evolutionary ecology, including naturally these elusive but determining organisms that our current ignorance calls signs, symbols or memes, can ecosemiotics be properly established as a comprehensive science.

\section{References}

Bouissac, Paul 1985. Neurosemiotics, a definition. Recherches sémiotiques / Semiotics Inquiry 5(3): 323-325.

- 1993. Ecology of semiotic space: Competition, exploitation and the evolution of arbitrary signs. The American Journal of Semiotics 10(3/4): 143-163.

Calder, Andrew; Lawrence, Andrew; Young, Andrew 2001. Neuropsychology of fear and loathing. Nature Reviews 2(5): 352-363.

Clare, Anthony 1985. Where lies the science? Nature 318: 112-113. 
Deacon, Terrence 1997. The Symbolic Species: The Co-evolution of Language and the Brain. New York: W.W. Norton \& Company.

- 1999. Memes as signs. The Semiotic Review of Books 10(3), 1-3.

Deely, John 1998. Augustine of Hippo. In: Bouissac, Paul (ed.), Encyclopedia of Semiotics. New York: Oxford University Press, 51-53.

Feynman, Richard 1999. The Pleasure of Finding Things Out. Cambridge MA: Perseus Publishing.

Harré, Rom; Brockmeier, Jens; Mühlhäusler, Peter (eds.) 1999. Greenspeak: A Study of Environmental Discourse. Thousands Oak: Sage.

Hoffmeyer, Jesper 1996. Signs of Meaning in the Universe. Bloomington: Indiana University Press.

Hornborg, Alf 1996. Ecology as semiotics. In: Descola, Philippe; Pálsson, Gísli (eds.), Nature and Society: Anthropological Perspectives. London: Routledge, 45-62.

Hull, David 1996. A revolutionary philosopher of science. Nature 382: 203-204.

Ivanov, Vyacheslav V. 1979. Nejrosemiotika ustnoj rechi i funkcional'naya asimmetriya mozga. In: Shelyakin, M. A. (ed.), Semiotika ustnoj rechi. (Acta et Commentationes Universitatis Tartuensis 481.) Tartu: Tartuskij Gosudarstvennyj Universitet, 121-142.

Kestenbaum, David 1998. Gentle force of entropy bridges disciplines. Science 279: 1848.

Koch, Walter 1986. Evolutionary Cultural Semiotics. Bochum: Brockmeyer.

Kull, Kalevi 2000. Copy versus translate, meme versus sign: Development of biological textuality. European Journal of Semiotic Studies 12(1): 101-120.

Lorenz, Konrad 1981. The Foundations of Ethology. New York: Springer Verlag.

Maturana, Humberto R.; Varela, Francisco J. 1987. The Tree of Knowledge: The Biological Roots of Human Understanding. Boston: New Science Library.

McKellar, Gordon Bruce 1987. The place of socio-semiotics in contemporary thought. In: Steele, R.; Threadgold, T. (eds.), Language Topics: Essays in Honour of Michael Halliday, vol. II. Amsterdam: John Benjamins Publishing Company, 523-548.

Nöth, Winfried 1998. Ecosemiotics. Sign Systems Studies 26: 332-343.

Pennisi, Elizabeth; Roush, Wade 1997. Developing a new view of evolution. Science 277: 34-37.

Piaget, Jean 1915. La mission de l'Idée. Lausanne: Edition La Concorde.

Roush, Wade; Pennisi, Elizabeth 1997. Growing pains: Evo-devo researchers straddle cultures. Science 277: 38-39.

Saussure, F. de 1989. Cours de linguistique générale. Critical edition by R. Engler. Wiesbaden: Otto Harrassowitz.

Sebeok, Thomas A. 1968. Goals and limitations of the study of animal communication. In: Sebeok, Thomas A. (ed.), Animal Communication. Bloomington: Indiana University Press, 3-15.

Zahavi, Amotz; Zahavi, Avishag 1997. The Handicap Principle: A Missing Piece of Darwin's Puzzle. New York: Oxford University Press. 


\section{О знаках, мемах и микроэлектромеханических системах: В направлении к эволюционной экосемиотике}

В данной статье поднимается вопрос: может ли семиотика придать какую-либо ценность экологии. Короткий обзор эпистемологического статуса семиотики в ее нынешних формах показывает, что феноменологические макроконцепции семиотики (которые исходят из разных теологических и философских традиций) не отвечают в своем объеме комплексности наук, составляющих экологию, и слишком редуктивны, чтоб успешно охарактеризовать те микропроцессы, посредством которых организмы развиваются и взаимодействуют. Тем не менее, имеются по менышей мере две причины, позволяющие соединению семиотики и экологии быть научно продуктивным: а) именно свобода семиотического дискурса может быпь существенным катализатором мультидисциплинарного взаимовлияния, - что является существенным условием для возникновения истинно холистической экологии; б) нынешний понятийный аппарат семиотики не "высечен на камне". Все ее концепты, теоретическое обрамление и модусы доказательств могут развиваться в соприкосновении с проблемами, которыми занимаются в эволюционно-экологических исследованиях. Семиотика как открытый эпистемологический проект остается интеллектуальной сокровищницей, открьтой для множества возможностей. Вторая тема статьи имеет целью привлечение внимания к возможности переосмысления и развития семиотического исследования благодаря недавним научным открытиями. Предпринимается попьтка показать, что антиинтуитивистские теории (такие, как меметика) и новый уровень технологии (как нанотехнология) позволяют экосемиотике подойти вплотную к решению разных задач, а не просто пересказывать экологический дискурс с помощью семиотических макроконцепций. Меметика и нанотехнология тут приведены не в качестве окончательных решений, а лишь как показатели возможных направлений в движении к всесторонней эволюционной экосемиотике, которая бы радикально изменила семиотический дискурс XX века и его идеологическую программу. 


\section{Märkidest, meemidest ja mikroelektromehhaanilistest süsteemidest: evolutsioonilise ökosemiootika suunas}

Esmalt tõstatatakse käesolevas artiklis küsimus, kas semiootika võib lisada mingit väärtust ökoloogiale. Lühike ülevaade semiootika epistemoloogilisest staatusest tema praegustes vormides näitab, et semiootika fenomenoloogilised makrokontseptsioonid (mis pärinevad mitmesugustest teoloogilistest ja filosoofilistest traditsioonidest) ei vasta oma ulatuselt nende teaduste komplekssusele, mis moodustavad ökoloogia, ning on liialt reduktiivsed kaardistamaks edukalt mikroprotsesse, mille kaudu organismid arenevad ning on vastasmõjus. On siiski vähemalt kaks põhjust, miks semiootika ja ökoloogia ühendus võib olla teaduslikult produktiivne: (a) just semiootilise diskursuse vabadus saab olla multidistiplinaarsete vastasmõjude oluline katalüsaator, oluline tingimus tõeliselt holistliku ökoloogia tekkimiseks; (b) semiootika praegune mõisteaparatuur ei ole kivisse raiutud. Kõik selle mõisted, teoreetiline raamistik ja põhjendusviisid võivad areneda kokkupuutes probleemidega, millega tegeletakse tänapäevases evolutsioonilis-ökoloogilises uurimistöös. Semiootika kui avatud epistemoloogiline projekt jääb võmalusterohkeks intellektuaalseks varamuks. Artikli teine teema on tõstatatud tähelepanu juhtimiseks hiljutiste teadusarengute poolt pakutavatele võimalustele semiootilise uurimise ümbermõtestamiseks ja edasiarendamiseks. Püütakse näidata, et vastuintuitiivsed teooriad (nagu memeetika) ning uus tase tehnoloogias (nagu nanotehnoloogia) võivad tuua ökosemiootika intellektuaalselt enam huvi pakkuvate uurimisteemade juurde kui seda on ökoloogilise diskursuse pelk ümberkirjutamine traditsiooniliste semiootiliste makrokontseptsioonide abil. Memeetika ja nanotehnoloogia ei ole siin muidugi esile toodud kui mingid kindlad lahendused, vaid lihtsalt kui suunaviited laiahaardelise evolutsioonilise ökosemiootika poole, mis muudaks radikaalselt 20. sajandi semiootilise diskursuse aluseid ning selle ideoloogilist kava. 